\title{
PERKULIAHAN MATA KULIAH KALKULUS I MELALUI SELF REGULATED LEARNING DENGAN MENGEMBANGKAN LEMBAR KEGIATAN MAHASISWA (LKM) BERBASIS MASALAH PROGRAM STUDI PENDIDIKAN MATEMATIKA UNIVERSITAS JEMBER
}

\author{
Abi Suwito \\ Dosen Universitas Jember
}

\begin{abstract}
Abstrak. Mata kuliah Kalkulus I merupakan salah satu mata kuliah wajib yang harus ditempuh di program studi matematika. Pengembangan LKM yang berbasis masalah melalui Self Regulated Learningdiharapkan aktivitas mahasiswa dalam perkuliahan Kalkulus I akan meningkat. Subyek penelitian adalah 35 mahasiswa yang menempuh mata kuliah Kalkulus I Program Studi Pendidikan Matematika tahun akademik 2013/2014. Langkah awal yaitu: Mengkaji karakteristik pembelajaran mata kuliah Kalkulus I di FKIP Universitas Jember, Mengkaji masalah peserta didik dalam pembelajaran, Mengkaji kompetensi yang harus dimiliki peserta didikselanjutnya mendesain perangkat pembelajaran yaitu mengembangkan LKM.

Dari hasil pengembangan LKM yang berbasis masalah melalui Self Regulated Learning diperoleh aktivitas mahasiswa sangat tinggi. Mahasiswa lebih banyak mengeluarkan ide/pendapat, berani bertanya, mau menganalisis dan menyelesaikan masalah.
\end{abstract}

Kata kunci :LKM, Self Regulated Learning, Berbasis Masalah

\section{PENDAHULUAN}

Hampir tidak ada lagi yang menyangsikan bahwa suatu model pembelajaran memiliki suatu peranan yang penting dalam kurikulum. Hal ini berkaitan dengan bagaimana suatu konsep tersebut diajarkan kepada peserta didik. Pentingnya model pembelajaran adalah untuk membantu pendidik dalam mengorganisasi pengalamanpengalaman belajar untuk mencapai tujuan belajar.

Dalam memberikan pembelajaran di kelas, masih banyak pendidik di tingkat pendidikan tinggi yang lebih mengutamakan pemberian informasi atau materi secara langsung dan peserta didik hanya sebagai penerima informasi. Seringkali dalam mengajar pendidik menjelaskan konsep, memberikan contoh penggunaan konsep dalam soal serta meminta peserta didik untuk latihan mengerjakan soal-soal. Hal ini tentu saja kurang melatih peserta didik dalam berpikir secara mandiri. Oleh karena itu, pengembangan suatu model pembelajaran seyogyanya dilakukan oleh pendidik guna memperbaiki kualitas pembelajaran di kelas.

Kualitas pembelajaran yang rendah akan menyebabkan terjadinya miskonsepsi yang seringkali terjadi pada peserta didik. Untuk mencegah hal tersebut terjadi maka diperlukan suatu model pembelajaran yang dapat mengakomodasi peserta didik untuk membangun pengetahuan berdasarkan pengalaman belajar. Sebagaimana pendapat Gagnon, G.W. Collay yaitu (1) all student, wheather youngsters or adult are honored by the assumption that they already know something, (2) most students and adult conception contain element of truth and those element can be basic for building new learning, (3) teacher and student together weave a tapestary of understanding when all are encourage to bring their ideas forward.

$$
\text { Menurut Yuwono (2005:2) }
$$

rendahnya hasil belajar peserta didik umumnya dipengaruhi banyak faktor, misalnya pembelajaran belum berjalan secara bermakna artinya peserta didik cenderung diberikan drill \& practice 
dan hafalan sebanyak-banyaknya. Hal ini berarti proses pembelajaran belum diupayakan untuk meningkatkan aktivitas mental ke arah penalaran yaitu berpikir logis dan kritis. Padahal salah satu kompetensi dari mahasiswa calon guru adalah kompetensi professional yaitu kemampuan dalam menguasai bahan belajar secara mendalam dan luas. Kompetensi tersebut akan tercapai apabila proses pembelajaran selalu memberikan kesempatan peserta didik mengkaji materi secara kritis.

Pengembangan LKM berbasis masalah merupakan salah satu upaya untuk meningkatkan kualitas pembelajaran. Kegiatan pengembangan dilakukan dalam waktu 6 bulan. Pertanyaan penelitian yang akan dijawab adalah bagaimana pengembangan dan hasil pengembangan lembar kegiatan mahasiswa pembelajaran berbasis masalah melalui self regulated learning yang valid, praktis dan efektif untuk membangun pengetahuan matematika mahasiswa calon pendidik.

Salah satu dugaan munculnya ketidakmampuan pengajar matematika untuk memotivasi peserta didik dalam menghargai serta memahami matematikaadalah sebagian besar pengajar, mengalami kurangnya keterampilan pemecahan masalah di dunia nyata. Oleh karena itu, pendidik di tingkat perguruan tinggi perlu menggunakan LKM berbasis masalah melalui self regulated learning. Dengan harapan, setelah dilakukan pembelajaran tersebut maka pengalaman belajar yang didapat di perguruan tinggi dapat mengasah kompetensi peserta didik.

Sejalan dengan pertanyaan penelitian, maka tujuan penelitian ini adalah untuk memperoleh model pembelajaran berbasis masalah melalui self regulated learning yang valid, praktis dan efektif untuk membangun pengetahuan matematika mahasiswa calon pendidik.
Pembelajaran bagi seorang calon peserta didik merupakan hal yang sangat strategis, karena dapat memberikan dampak langsung dan dampak tidak langsung. Dampak langsung yang didapat yaitu oleh calon peserta didik tersebut setelah pembelajaran. Sedangkan dampak tidak langsung adalah dampak yang akan mempengaruhi mereka dalam mengelola pembelajaran ketika mereka menjadi seorang pendidik nantinya.

Penelitian ini diadakan sebagai upaya dalam memberikan suatu pencerahan dalam mengelola proses pembelajaran dan salah satunya adalah model pembelajaran. Adanya suatu LKM berbasis masalah melalui self regulated learning yang valid, praktis dan efektif diharapkan menjadi salah satu alternative pembelajaran di tingkat perguruan tinggi yang memberikan kesempatan kepada peserta didik untuk belajar matematika dengan mandiri, kreatif dan kritis. pengembangan ini diharapkan dapat memberikan sumbangan terhadap kurikulum berupa model pembelajaran pembelajaran berbasis masalah melalui self regulated learningyang dapat digunakan di Universitas Jember.

Penelitian yang kami ajukan memiliki keunggulan yaitu diperolehnya prototype LKM berbasis masalah melalui self regulated learningyang memberikan kesempatan peserta didik untuk membangun pengetahuan dalam hal ini mempelajari, menganalisis dan merefleksi materi atau konsep yang diajarkan secara mandiri. Sehingga mereka dapat mengaplikasikannya dalam memecahkan masalah yang berkaitan dengan matematika khususnya di bidang Kakulus.

Pengembangan LKM berbasis masalah melalui self regulated learning yang valid, praktis dan efektif memiliki keterbatasan pada pemilihan materi kalkulus yaitu Kalkulus I serta subjek uji coba penelitian yaitu pada mahasiswa 
Universitas Jember pada semester I kelas C tahun akademik 2013/2014.

Arends dalam Trianto (2010; 22-23) menyatakan the term teaching model refers to a particular approach to instruction that includes its goals syntax, environment, and management system. Model pembelajaran mengarah pada suatu pendekatan pembelajaran terterntu termasuk tujuan, sintak, lingkungan dan system pengelolaannya. Dengan demikian model pembelajaran memiliki makna yang lebih luas daripada strategi, metode atau prosedur.

Pandangan Parta $\quad(2009 ; 12)$ mengenai model pembelajaran adalah suatu kerangka yang memuat (1) rasional teoritik yang logis, (2) perilaku siswa belajar dan guru mengajar, (3) situasi kelas, (4) tujuan pembelajaran dan (5) bahan ajar yang membentuk sistem kerja. Keseluruhan aspek merupakan prosedur yang sistematis dalam mengelola pengalaman belajar untuk mencapai tujuan belajar.

Komponen model pembelajaran menurut Joyce, Bruce and Weil, Marsha (1992:14-16) yaitu (1) sintak , (2) system social, (3) prinsip reaksi serta (4) system pendukung. Berikut ini adalah uraian dari tiap-tiap komponen:

1) Sintak

Sintak mendiskripsikan

bagaimana model itu

dilaksanakan. Dengan kata lain

sintak mendiskripsikan secara logis aktifitas pendidik dan peserta didik yang biasa disebut fase. Dalam sintak diuraikan, bagaimana membuka pembelajaran, bagaimana menyajikan materi, bagian manakah dari materi itu harus disajikan, apa yang harus dilakukan pengajar dan peserta didik, bagaimana bentuk keterlibatan peserta didik dan seterusnya (Arend, 1997:8) dalam Parta.

2) Sistem Sosial
Sistem sosial mendeskrepsikan peranan pendidik dan peserta didik, hubungan satu sama lain, serta target yang diharapkan. Fungsi managerial pendidik sangat bervariasi tergantung kepada ciri model itu. Sebagai contoh, dalam model pembelajaran langsung maka aktifitas pembelajaran terpusat pada pendidik, karena modelini bersifat teacher centered. Tetapi dalam model lain aktifitas mungkin tersebar merata antara pendidik dan peserta didik.

3) Prinsip Reaksi

Prinsip reaksi memberi pegangan bagi pendidik tentang cara memandang dan merespon kinerja atau performance peserta didik. Dalam model yang bercirikan student centered peserta didik harus dipandang sebagai sumber informasi, sehingga peranan pendidik lebih bersifat konsultatif dalam merespon hasil kerja peserta didik.

4) Sistem Pendukung

Agar model pembelajaran dapat diterapkan maka perlu ada system pendukung. Parta (2009;14-15) menyatakan secara definitive, dapat dikatakan bahwa system pendukung adalah syarat tambahan dari model selain ketrampilan, kekuatan, dan kemampuan rutin. Syarat tambahan tersebut dapat berupa fisik maupun non fisik. Yang termasuk syarat fisik meliputi perangkat pembelajaran, bahan ajar, alat peraga dan sebagainya. Sedangkan syarat non fisik antara lain (1) secara psikis peserta didik siap menerima pembelajaran, (2) peserta didik berada dalam suatu lingkungan yang memungkinkan 
pembelajaran berlangsung (tidak dalam keadaan tertekan), (3) pendidik mampu mengelola pembelajaran, (4) adanya komunikasi yang harmonis antara pendidik dan peserta didik (misalnya pendidik tidak dibenci atau dimusuhi peserta didik dan sebaliknya).

Model Pembelajaran Berbasis Masalah (PBM)dikenal dengan beberapa istilah lain diantaranya adalah projectbased-instruction (pengajaran berbasisproyek), authentic learning (pembelajaran autentik), dananchored instruction (pengajaran berakar pada kehidupan nyata). Secara umum PBM menyajikan berbagai masalah yang autentik dan bermakna, yang dapat berfungsi sebagai pendorong kepada peserta didik untuk melakukan penyelidikan dan inquiry (Arends, 2008:41).

Karakteristik pembelajaran berbasis masalah antara lain 1). Pengajuan pertanyaan atau masalah, 2) fokus pada keterkaitan antar disiplin ilmu yang lain, 3) Penyelidikan autentik, 4) menghasilkan produk atau karya, serta 5) kerjasama. Ibrahim (2005:1415) mengemukakan tujuan dari PBM sebagai berikut..(1) Mengembangkan ketrampilan berpikir dan menyelesaikan masalah, (2) Pemodelan peranan orang dewasa, (3) Pebelajar otonom dan mandiri. Melalui PBM diharapkan peserta didik secara berangsur-angsur dilatih untuk menjadi pebelajar yang mandiri (self regulated learning).

PBM dipilh pada penelitian ini karena beberapa pertimbangan, yaitu: (1) pada awal pembelajarannya dimulai dengan pengajuan masalah yang autentik dan bermakna, sehingga diharapkan peserta didik lebih memahami konsep yang diajarkan sebab mereka sendiri yang menemukan konsep tersebut, (2) melibatkan secara aktif penyelesaian masalah dan menuntut ketrampilan berpikir peserta didik yang lebih tinggi, (3) pengetahuan tertanam berdasarkan skemata yang dimiliki peserta didik sehingga pembelajaran lebih bermakna

Menurut Pintrich (dalam Boekaert et.al, 2000:453), secara umum self regulated learning didefinisikan sebagai proses konstruktif ketika siswa menetapkan tujuan belajar sekaligus mencoba memantau, mengatur, dan mengendalikan pengamatan, motivasi serta perilakunya yang dibatasi oleh tujuan belajar dan kondisi lingkungan. Sejalan dengan hal tersebut, Elvina (2008) menyatakan bahwa self regulated learning adalah suatu upaya mahasiswa untuk aktif mengembangkan pengetahuan yang didapat dengan menggunakan cara-cara yang relevan dan tidak terbatas pada materi yang diperoleh di lingkungan sekolah.

Slavin (2007) mengemukakan bahwa pengembangan kemampuan self regulated learningpada dasarnya dapat dilakukan melalui strategi berikut: 1) Menganalisis tugas dan menetapkan suatu tujuan, 2) Memotivasi diri untuk menerapkan strategi belajar yang efektif, 3) Memonitor kegiatan pembelajaran

\section{METODE PENELITIAN}

Untuk diperoleh produk pengembangan yang baik, perlu ditempuh suatu prosedur tertentu, yakni mengacu pada model pengembangan. Pada penelitian ini yang digunakan untuk pengembangan LKM, model pembelajaran PBM melalui self regulated learningadalah Model pengembangan ADDIE. Model pengembangan ADDIE merupakan suatu model dalammendesain suatu perangkat pendidikan yang terbagi dalam 5 fase, yaitu:1) Fase Analisis, 2) Fase Desain, 3) Fase Pengembangan, 4) Fase Implementasi 5) Fase Evaluasi.

\section{A. Teknik Analisis}

Pengembangan LKM ini meliputi kegiatan penulisan prototype LKM, 
perangkat pembelajaran serta instrument penelitian, review (ahli dan praktisi), revisi, uji coba dan revisi akhir. Review dilakukan oleh tiga orangahli yang memiliki kompeten di bidang Kalkulus dan tiga orang pendidik untuk mendapatkan masukan sebagai bahan perbaikan sebelum prototype LKM, perangkat pembelajaran serta instrument penelitian diujicobakan. Uji coba dilakukan pada peserta didik kelas c Prodi Pendidikan Matematika Semester Gasal 2013/2014 FKIP Universitas Jember. Uji coba dimaksudkan untuk mendapatkan masukan dari lapangan (Mahasiswa calon pendidik FKIP Universitas Jember) untuk bahan perbaikan.

Uji coba akan dilakukan dalam dua tahap yaitu: 1) Uji coba kelompok kecil,

Uji coba kelompok kecil termasuk validasi empirik terhadap produk. Uji coba ini dilakukan terhadap empat mahasiswa calon pendidik FKIP Universitas Jember yang memiliki kemampuan yang bervariasi (tinggi, sedang dan rendah). 2) Uji coba lapangan, Uji coba lapangan yang akan dilakukan pada Mahasiswa calon pendidik FKIP Universitas Jember secara klasikal. Hal ini bertujuan untuk mengetahui kepraktisan dan keefektifan dari produk yang dikembangkan. Apabila hasil analisis menunjukkan revisi besar maka dilakukan uji lapangan kembali dengan mengambil subjek uji coba selain yang sudah digunakan sebagai subjek uji coba. Sebaliknya apabila hasil analisis menunjukkan produk praktis dan efektif maka uji coba lapangan telah selesai dan dihasilkan draft akhir dari produk yang valid, praktis dan efektif.

Seluruh data yang diperoleh dalam penelitian ini dikelompokkan menjadi dua jenis yaitu: data kualitatif dan data kuantitatif. Data kualitatif berupa tanggapan, koreksi ataupun saran yang diperoleh melalui angket, lembar validasi, lembar keterlaksanaan dan wawancara, baik terhadap para ahli, pendidik maupun peserta didik. Sedangkan data kuantitatif berupa skor peserta didik dalam mengerjakan tes di akhir pembelajaran geometri.

Instrumen yang dikembangkan dalam penelitian ini antara lain berupa lembar validasi, lembar observasi keterlaksanaan model pengembangan, lembar observasi mahasiswa, soal tes an angket. Selain lembar validasi, seluruh instrumen dalam penelitian ini divalidasi oleh ahli sebelum digunakan di lapangan. Dalam menyusun instrumen, peneliti selalu mengontrol kesesuaian antara produk yang dihasilkan, instrumen dan pendekatan pembelajaran yang digunakan dalam penelitian.

Instrumen-instrumen tersebut akan digunakan untuk mendapatkan data yang akan yang direkam dalam pengembangan model pembelajaran. Berikut ini tabel yang menunjukkan kesesuaian antara instrumen dan data yang direkam

Tabel 1 Kesesuaian antara instrumen dengan data yang direkam

\begin{tabular}{|l|l|l|l|}
\hline Aspek yang diamati & Instrumen & Data yang direkam & Responden \\
\hline $\begin{array}{l}\text { Kevalidan model } \\
\text { pembelajaran }\end{array}$ & Lembar validasi & $\begin{array}{l}\text { Kevalidan model } \\
\text { pembelajaran }\end{array}$ & $\begin{array}{l}\text { Ahli dan praktisi } \\
\text { (pendidik) }\end{array}$ \\
\hline $\begin{array}{l}\text { Kepraktisan model } \\
\text { pembelajaran }\end{array}$ & $\begin{array}{l}\text { Lembar observasi } \\
\text { keterlaksanaan model } \\
\text { pembelajaran }\end{array}$ & $\begin{array}{l}\text { Keterlaksanaan model } \\
\text { pembelajaran }\end{array}$ & Pengamat (Pendidik) \\
\hline $\begin{array}{l}\text { Keefektifan model } \\
\text { pembelajaran }\end{array}$ & $\begin{array}{l}\text { Tes } \\
\text { Angket } \\
\text { Lembar observasi } \\
\text { aktivitas siswa }\end{array}$ & $\begin{array}{l}\text { Penguasaan materi } \\
\text { Respon Peserta Didik } \\
\text { Aktivitas Peserta Didik }\end{array}$ & $\begin{array}{l}\text { Subjek penelitian } \\
\text { (Mahasiswa calon } \\
\text { pendidik FKIP } \\
\text { Universitas Jember) }\end{array}$ \\
\hline
\end{tabular}


Analisis hasil validasi yang diperoleh dari validator bersifat deskriptif. Analisis ini digunakan untuk mengolah data yang berupa saran dan komentar dari review ahli, praktisi, validasi empiris dan uji coba lapangan.Hasil analisis data ini kemudian digunakan sebagai acuan untuk merevisi produk pengembangan yang berupa model pembelajaran.

Kriteria kevalidan, kepraktisan dan kefektifan produk dalam penelitian pengembangan ini dimodifikasi berdasarkan pendapat Hobri (2010) bahwa Suatu produk dikatakan valid apabila sekurang-kurangnya validator ahli (Dosen) menyatakan bahwa produk dapat digunakan dan memiliki derajat validitas yang baik yaitu apabila sekurang-kurangnya mencapai tingkat valid. Kepraktisan suatu produk apabila sekurang-kurangnya praktisi lapangan (pendidik) menyatakan bahwa pembelajaran menjadi mudah apabila menggunakan produk yang dihasilkan yaitu memiliki derajat kepraktisan yang baik (sesuai). Keefektifan suatu produk apabila sekurang-kurangnya $80 \%$ peserta didik memenuhi kriteria skor hasil belajar peserta didik sedikitnya $75 \%$ dari skor maksimal dan peserta didik memberikan respon yang positif.

Kegiatan penentuan nilai ratarata total aspek kevalidan model pembelajaran yang diadaptasi dari Hobri (2010) adalah sebagai berikut.

1. Melakukan rekapitulasi data kevalidan model dalam tabel meliputi aspek $\left(\mathrm{A}_{\mathrm{i}}\right)$, indikator (I), dan nilai $\mathrm{V}_{\mathrm{ji}}$ untuk masing-masing validator

2. Menentukan rata-rata nilai hasil validasi dari semua validator untuk setiap indikator dengan rumus $I_{i}=\frac{\sum_{j-i}^{n} V i j}{n}$, dengan

Vij adalah data nilai validator ke-j terhadap indikator ke-i

$\mathrm{n}$ adalah banyaknya validator
3. Menentukan rerata nilai untuk setiap aspek dengan rumus sebagai berikut.

$$
A_{i}=\frac{\sum_{j=i}^{n} I_{i j}}{m}
$$

Dengan Ai adalah rerata nilai untuk aspek ke-i

Iij adalah rerata untuk aspek ke-I indikator ke-j

$\mathrm{m}$ adalah banyaknya indikator dalam aspak ke-i

4. Menentukan nilai $\mathrm{Va}$ atau nilai rerata total dari rerata nilai untuk semua aspek dengan rumus. $V_{a}=\frac{\sum_{i=1}^{n} A_{i}}{n}$ dengan

Va adalah nilai rerata total untuk semua aspek

$\mathrm{n}$ adalah banyaknya aspek

5. Selanjutnya nilai Va dirujuk pada interval penentuan tingkat kevalidan model pembelajaran sebagai berikut.

$$
\begin{aligned}
& 0 \leq V a<1 \\
& \text { valid) } \\
& 1 \leq V a<2 \\
& \text { valid) } \\
& 2 \leq V a \leq 3 \text { (valid) }
\end{aligned}
$$

Pembagian interval tersebut dilakukan supaya peluang kevalidan tiap-tiap aspek adalah sama.

Analisis

observasi keterlaksanaan model pembelajaran akan dilakukan serupa dengan analisis hasil validasi, akan tetapi perbedaannya yaitu setelah menentukan nilai rata-rata tiap aspek kepraktisan pada masingmasing observer (Ai) kemudian menghitung rata-rata tiap aspek tersebut (Rt2 Ai). Selanjutnya ditentukan ratarata seluruh aspek (Va). Karena rentang skor ini adalah 0 sampai 3, maka panjang interval dalam rentang skor ini adalah 3. Selanjutnya interval tersebut dibagi menjadi tiga sub interval tingkat kepraktisan seperti berikut. 
$0 \leq V a<1$ (rendah)

$1 \leq V a<2$ (cukup tinggi)

$2 \leq V a \leq 3$ (tinggi)

Sedangkan untuk menganalisis keefektifan yang didasarkan lembar observasi aktivitas siswa menggunakan langkah-langkah yang sejalan dengan analisis lembar keterlaksanaan model pembelajaran. Akan tetapi, kriteria tingkat keefektifan yang digunakan berbeda yaitu.

$$
\begin{aligned}
& 0 \leq V a<1 \\
& \text { aktif) } \\
& 1 \leq V a<2 \\
& \text { aktif) } \\
& 2 \leq V a \leq 3 \text { (cukup }
\end{aligned}
$$

Untuk menganalisis keefektifan yang didasarkan pada penguasaan materi peserta didik digunakan instrumen tes. Rumus yang digunakan seperti dibawah ini.

$$
T B=\frac{t}{N} \times 100 \%
$$

Keterangan:

TB adalah angka presentase ketuntasan belajar

$\mathrm{t}$ adalah banyaknya peserta didik yang mendapatkan skor $\geq 75$

$\mathrm{N}$ adalah banyaknya peserta didik yang mengikuti tes.

Analisis data keefektifan yang lain yaitu melalui angket yang diberikan kepada peserta didik setelah pelaksanaan pembelajaran.

\section{KESIMPULAN}

Dari pelaksanaan pembelajaran dengan model pembelajaran Self Regulated Learing melalui pengembangan LKM, aktivitas mahasiswa dalam pembelajaran mata kuliah Kalkulus I sangat tinggi, mahasiswa lebih mampu mengeluarkan ide/pendapatnya dalam penyelesaian masalah, karena dalam LKM yang memuat yaitu tugas, wacana, lingkungan belajar dan analisis. Dengan adanya tugas-tugas yang disertai dengan wacana menyebabkan mahasiswa berdiskusi dan berani bertanya. Sehingga model pembelajaran Self Regulated Learning melalui pengembanganLKM dapat meningkatkan aktivitas belajar mahasiswa pada mata kuliah Kalkulus I.

\section{DAFTAR PUSTAKA}

Amelia, Elvina. 2008. Hubungan self regulated learning dengan kemampuan memecahkan masalah pada siswa SMU 53 di Jakarta Timur. http://www.gunadarma.ac.id/li brary/articles/graduate/psycho logy/2008/Artikel_10404005. pdf(diakses 17 Juli 2013)

Arends, Richard.I. 2008. Learning to Teach. New York: Mc Graw Hill Companies.

Boekaerts, M., Pintrinch,P\& Zeidner, M. 2000. Handbook of self regulation. California: Academic Press.

Gagnon,G.W., Collay, M. 2001. Designing for Learning: Six Element in Construstivist Classroom. Thousand Oaks, California. Corwin Press, INC

Hobri. 2010. Metodologi Penelitian Pengembangan (Aplikasi pada Penelitian Pendidikan Matematika). Jember: Pena Salsabila.

Ibrahim, M. 2005. Pembelajaran Berdasarkan Masalah: Latar Belakang, Konsep Dasar dan Contoh Implementasinya. Surabaya: University Press.

Parta, I.N. 2009. Pengembangan Model Pembelajaran Inquiry untuk 
Memperhalus Pengetahuan Matematika Mahasiswa Calon Guru melalui Pengajuan Pertanyaan. Disertasi tidak diterbitkan. Surabaya: PPs UNESA.

Sugiono, 2010.Metode Penelitian Pendidikan. Bandung: Alfabeta.

Trianto. 2010. Mendesain Model Pembelajaran InovatifProgresif: Konsep, Landasan, dan Implementasinya pada Kurikulum Tingkat Satuan Pendidikan (KTSP). Jakarta: Kencana Prenada Media Group.

Yuwono, I. 2005. Pengembangan Model Pembelajaran Matematika secara Membumi. Disertasi tidak diterbitkan. Surabaya: PPs UNESA. 